\title{
Identification of the Anthocyanin Present in the Acerola which Produces Color Changes in the Juice on Pasteurization and Canning
}

\author{
Rafael Santini, Jr., and Alice Huyke ${ }^{1}$
}

\section{INTRODUCTION}

Acerolas have been shown by Asenjo and Freire de Guzmán (1), to be a good natural source of ascorbic acid. The ascorbic acid content of the juice suffers little change when the juice is pasteurized and canned $(2,3)$. However, the acerola juice darkens and there is a concurrent loss of flavor on pasteurization and canning.

After pasteurization the deep bright-red color of the acerola juice changes to yellowish and, upon standing several months at room temperature, it becomes brown and $\mathrm{CO}_{2}$ gas, which causes swelling of the cans, is produced. This change in color limits the usefulness of the acerola juice and it was felt that there was need of determining its cause.

\section{PROCEDURE}

The following evidence suggested that the red color present in the acerola juice was caused by an anthocyanin pigment: 1, The spectrophotometric curves of the juice shown in figure 1 display an absorption band between 500 and $220 \mathrm{~m} \mu$ (4). 2, An isobutyl alcohol extract of the fruit shows the characteristic anthocyanin blue-purple band at the top of a chromatographic column filled with activated alumina (6).

The method used by Sondheimer and Kertesz (4) for the isolation and crystallization of the anthocyanin pigment present in strawberries was adapted for the acerola and may be summarized as follows: Frozen acerolas were pressed after they had thawed sufficiently at room temperature. The 50 l. of juice obtained were saturated with sodium chloride. The $\mathrm{NaCl}$ saturated juice was divided into 5-1. portions and each portion was extracted with $1.25 \mathrm{l}$. of butanol. The butanol extracts were combined and concentrated in vacuo to about $1,000 \mathrm{ml}$. The crude pigment was precipitated by the addition of $5 \mathrm{l}$. of anhydrous ether. After standing for about 2 hours, the supernatant liquid was filtered and discarded. The precipitate was washed several times with $300-\mathrm{ml}$. portions of anhydrous ether. The yield of crude concentrate was $20 \mathrm{gm}$. The granular pigment was dissolved

1 Associate Chemist and Research Assistant, respectively, Agricultural Experiment Station, University of Puerto Rico, Río Piedras, P. R.

2 Numbers in parentheses refer to Literature Cited p. 178. 
172 JOURNAL OF AGRICULTURE OF UNIVERSITY OF PUERTO RICO

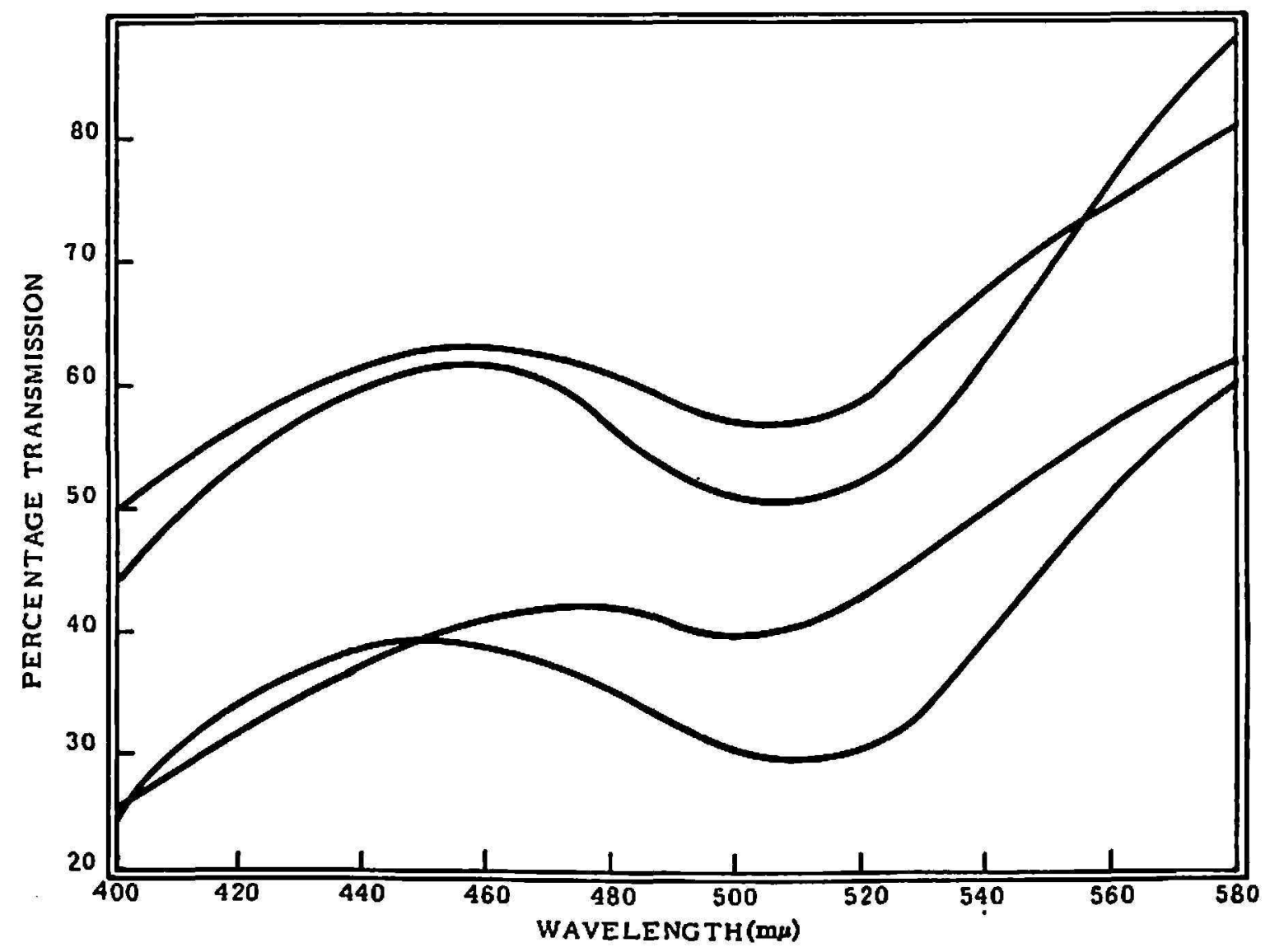

Fic. 1.-Absorption curves of 4 different samples of. fresh acerola juice.

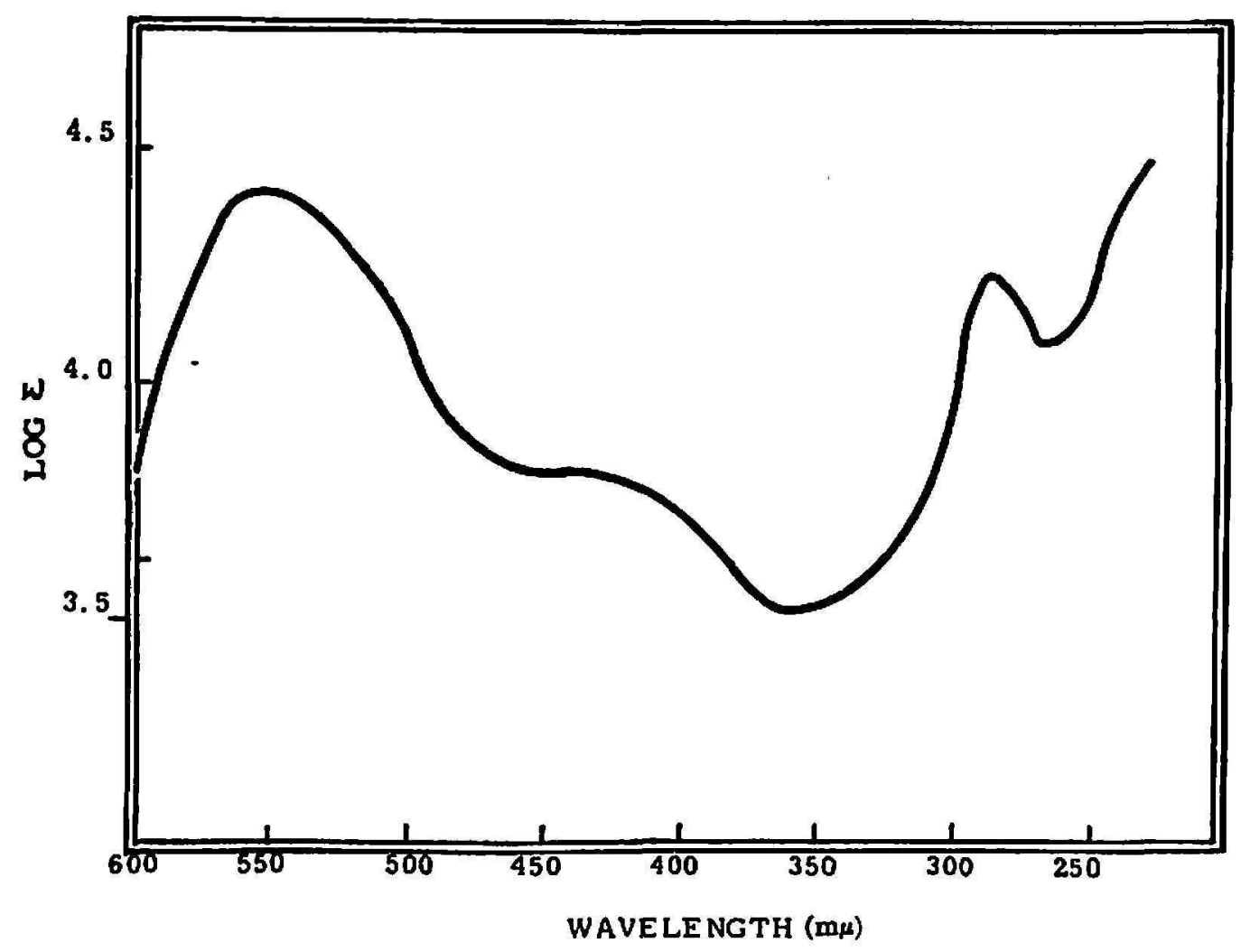

FIG. 2.-Absorption curve of the anthocyanin isolated from acerola juice. 
in $500 \mathrm{ml}$. of 0.01 -percent $\mathrm{HCl}$, filtered, saturated with picric acid, and stored at $0^{\circ} \mathrm{C}$. for 48 hours.

The crude-picrate preparation was completely soluble in $50 \mathrm{ml}$. of ethanol, containing 5 percent of $\mathrm{HCl}$. One liter of anhydrous ether precipitated flocculent anthocyanin chloride. After standing 2 hours at $0^{\circ} \mathrm{C}$., the mixture was filtered and the precipitate thoroughly washed with ether. This preparation was still impure and was therefore reconverted first to the picrate and then to the chloride. The purified chloride was dissolved in $4 \mathrm{ml}$. of methanol and $1.5 \mathrm{ml}$. of 12 -percent $\mathrm{HCl}$ were added. This solution was allowed to evaporate at room temperature. After 24 hours the crystals of the anthocyanin were obtained and were dried at $50^{\circ} \mathrm{C}$. for 2 hours. The final yield of the crystalline anthocyanin was $800 \mathrm{mg}$.

TABLE 1.-Color reactions of the anthocyanin obtained from the acerola and of malvidin chloride in buffered solutions of different $p H$ values

\begin{tabular}{|c|c|c|}
\hline $\mathrm{pH}$ of the buffer solution & Anthocyanin obtained from the acerola & Malvidin chloride \\
\hline 3.8 & $\begin{array}{l}\text { Bluish red; changes to pink } \\
\text { and quickly decolorizes }\end{array}$ & $\begin{array}{l}\text { Bluish red; changing rapidly } \\
\text { to pink and quickly de- } \\
\text { colorizing }\end{array}$ \\
\hline 6.0 & Violet & Violet, fading slowly \\
\hline 7.0 & Violet blue & Violet blue \\
\hline 8.0 & Blue & Blue \\
\hline 10.4 & $\begin{array}{l}\text { Blue, changing to greenish } \\
\text { blue }\end{array}$ & $\begin{array}{l}\text { Blue, changing to greenish } \\
\text { blue }\end{array}$ \\
\hline 11.8 & $\begin{array}{l}\text { Blue, fading rapidly to pale } \\
\text { green }\end{array}$ & $\begin{array}{l}\text { Blue, fading rapidly to pale } \\
\text { green }\end{array}$ \\
\hline
\end{tabular}

\section{RESULTS}

The absorption curve of the anthocyanin crystallized from the acerola shown in figure 2 was obtained with a Beckman Spectrophotometer, Model DU, using 1-cm. quartz cells. The molar-extinction coefficients were calculated and plotted against the wavelength. The curve is identical with that obtained for delphinidin, malvidin, and hirsutidin $(7,8)$.

The anthocyanin obtained was slightly soluble in water, giving a redviolet solution. It reduced Fehling's solution when boiled, and first gave a violet solution with sodium hydroxide which, upon addition of more sodium hydroxide, changed to greenish-blue. The color disappeared from the very dilute solution when heated. All these properties are identical with those listed for hirsutin and malvin (7).

Although the melting points of anthocyanin are accompanied by decomposition and are of no value for identification purposes (8), it was decided to run several melting-point determinations. No melting point 
was obtained with the anthocyanin crystallized from the acerola when heated above $300^{\circ} \mathrm{C}$. This agrees with the information found in the literature for malvin chloride (9).

TABLE 2.-Changes in ascorbic acid, red coloration, and optical density of different samples of acerola juice when stored at room temperature

\begin{tabular}{|c|c|c|c|}
\hline Sample and age of juice in days & $\begin{array}{l}\text { Ascorbic acid per } \\
100 \mathrm{ml} \text {. juice }\end{array}$ & $\begin{array}{r}\text { Red color as Congo } \\
\text { Red per } 100 \text { ml. juice }\end{array}$ & $\begin{array}{l}\text { Optical Density } \\
420 \mathrm{m \mu}\end{array}$ \\
\hline & $G m$. & $\mathbf{J g}_{\mathrm{g}}$ & \\
\hline \multicolumn{4}{|l|}{ Sample I: } \\
\hline 0 (fresh) & 1.442 & 3.70 & 0.235 \\
\hline 0 (after pasteurization) & 1.440 & 1.90 & .249 \\
\hline 3 & 1.404 & .85 & .345 \\
\hline 5 & 1.343 & .40 & .385 \\
\hline 8 & 1.329 & .10 & .398 \\
\hline 11 & 1.312 & 0 & .435 \\
\hline 18 & 1.274 & 0 & .540 \\
\hline 30 & 1.264 & 0 & .580 \\
\hline 60 & 1.177 & 0 & .740 \\
\hline \multicolumn{4}{|l|}{ Sample II: } \\
\hline 0 (fresh) & 1.025 & 3.10 & .215 \\
\hline 0 (after pasteurization) & 1.014 & 1.15 & .365 \\
\hline 3 & .993 & .40 & .450 \\
\hline 6 & .962 & 0 & .495 \\
\hline 14 & .914 & $\mathbf{0}$ & .750 \\
\hline 30 & .877 & 0 & .780 \\
\hline 60 & .806 & 0 & .850 \\
\hline \multicolumn{4}{|l|}{ Sample III: } \\
\hline 0 (fresh) & 1.257 & 5.50 & .225 \\
\hline 0 (after pasteurization) & 1.254 & 2.20 & .310 \\
\hline 3 & 1.247 & .75 & .410 \\
\hline 10 & 1.174 & 0 & .518 \\
\hline 30 & 1.122 & 0 & .690 \\
\hline 60 & 1.061 & 0 & .730 \\
\hline \multicolumn{4}{|l|}{ Sample IV: } \\
\hline 0 (fresh) & 1.342 & 3.50 & .228 \\
\hline 0 (after pasteurization) & 1.318 & 1.40 & .300 \\
\hline 3 & 1.261 & .35 & .350 \\
\hline 10 & 1.220 & .20 & .445 \\
\hline 30 & 1.168 & 0 & .565 \\
\hline 60 & 1.108 & 0 & .670 \\
\hline
\end{tabular}

The examination of the reaction of anthocyanins on a range of buffered solutions has shown that this method is by far the most reliable for purposes of comparison and characterization (8).

Buffered solutions were prepared at different pHs. The colors obtained 
(table 1) were identical with those found in the literature for malyidin chloride (10).

Several samples of acerola juice were prepared and stored at room temperature and $0^{\circ} \mathrm{C}$. for 2 months. Data on the ascorbic acid content, red coloration, and optical density at $420 \mathrm{~m} \mu$ were obtained and are shown in tables 2 and 3.

The method used for the quantitative determination of the red color in the strawberries (5) was adapted for the acerola and may be summarized as follows: Measuring the light absorption of the juice at $500 \mathrm{~m} \mu$ and at $\mathrm{pHs}$

TABLE 3.-Changes in ascorbic acid, red coloration, and optical density of different samples of acerola juice when stored at $0^{\circ} \mathrm{C}$.

\begin{tabular}{c|c|c|c}
\hline $\begin{array}{c}\text { Samples and age of } \\
\text { juice in days }\end{array}$ & $\begin{array}{c}\text { Ascorbic acid per } \\
100 \text { ml. juice }\end{array}$ & $\begin{array}{c}\text { Red color as Congo } \\
\text { Red per } 100 \text { ml. juice }\end{array}$ & Optical density $420 \mathrm{~m} s$ \\
\cline { 1 - 3 } Sample I: & Gm. & M/g. & \\
0 & 1.442 & 3.70 & 0.235 \\
3 & 1.417 & 3.70 & .220 \\
5 & 1.387 & 2.95 & .210 \\
8 & 1.361 & 3.10 & .190 \\
11 & 1.360 & 2.30 & .200 \\
18 & 1.360 & 2.20 & .210 \\
30 & 1.354 & 2.25 & .190 \\
60 & 1.351 & 2.00 & .210 \\
90 & & & \\
Sample II: & 1.342 & 3.60 & .228 \\
0 & 1.235 & 3.65 & .180 \\
3 & 1.234 & 3.10 & .160 \\
10 & 1.237 & 3.65 & .190 \\
24 & 1.136 & 2.45 & .240 \\
60 & & & \\
\hline
\end{tabular}

of 3.40 and 2.00. The measurement consisted of substracting the optical density at $500 \mathrm{~m} \mu$ of juice at a $\mathrm{pH}$ of 3.4 from its optical density at a $\mathrm{pH}$ of 2.00 , at a known concentration. The increase in color intensity under such conditions is proportional to the concentration of red color in the solution. A solution of Congo Red, which follows Beer's Law (fig. 3) was used as a standard of color intensity and the results are expressed as milligrams of Congo Red per $100 \mathrm{ml}$. of juice.

The ascorbic acid content was determined by the iodate method (11).

The increase in the darkening of the juice was determined by measuring the optical density at $420 \mathrm{~m} \mu$ (12) in samples of juice at a known concentration.

Figure 4 shows how the absorption band obtained at $520 \mathrm{~m} \mu$ in fresh acerola 
juice decreased in intensity after pasteurization and disappeared during storage at room temperature. The change was not so rapid in frozen juices (fig. 5). This agrees with the values obtained in the quantitative determination of red color given in tables 2 and 3.

\section{DISCUSSION}

It has been shown in table 2 that the ascorbic acid decreased and the red color disappeared in juices stored at room temperature, while the optical

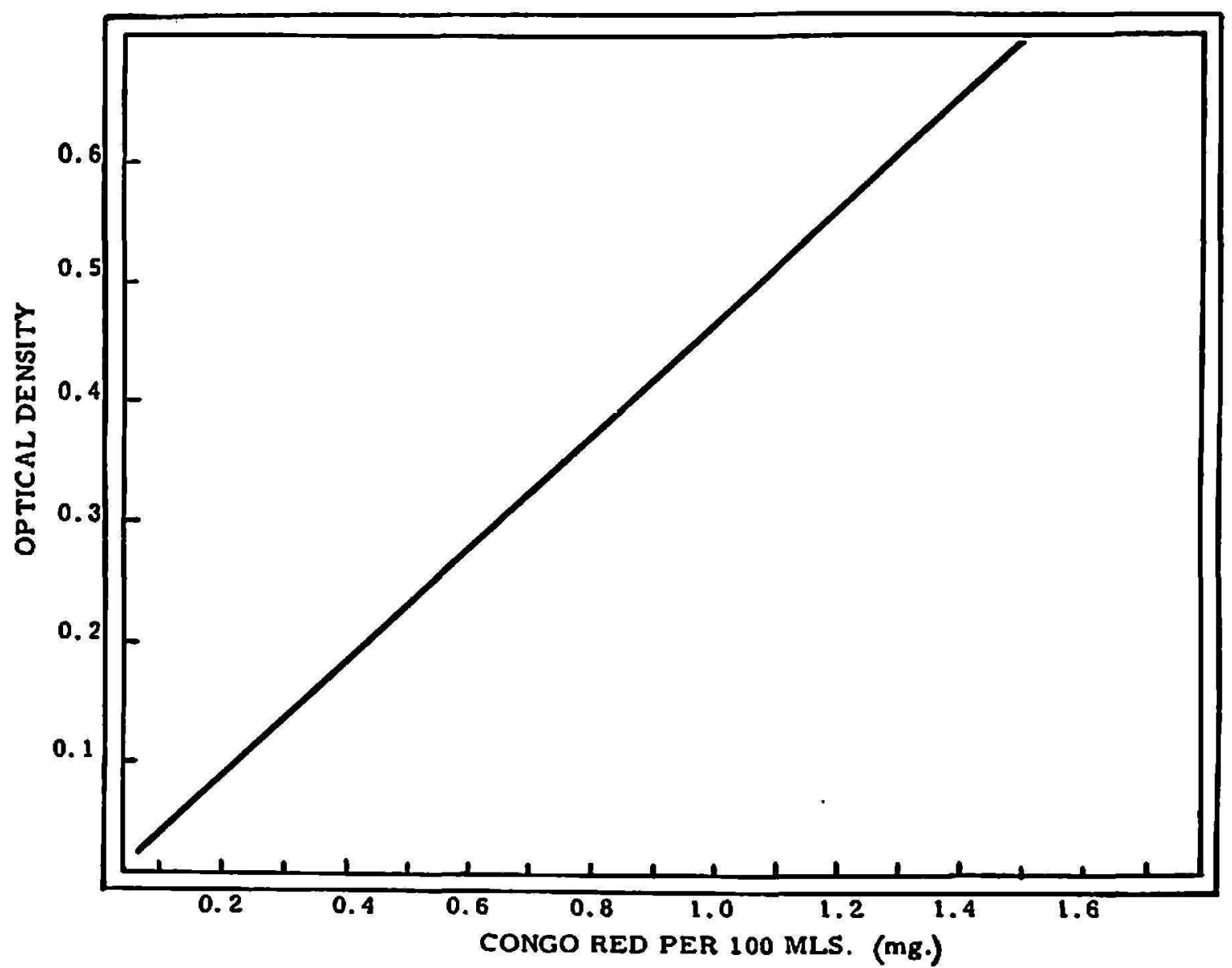

FIG. 3.-Standard transmission-concentration curve prepared using a solution of Congo Red in $0.01 \mathrm{~N} \mathrm{Na}_{2} \mathrm{CO}_{3}$.

density at $420 \mathrm{~m} \mu$ increased. In frozen juices (table 3 ) the amount of ascorbic acid and of red coloration decreased less rapidly, while the optical density either remained constant or decreased, and no brown color was observed in these juices during the storage period.

All evidence presented in this paper suggests that two main types of nonenzymatic reactions occur in the acerola juice. In one the red color is lost and in the other secondary brown pigments develop.

The data presented in tables 2 and 3 suggest that ascorbic acid is probably one of the constituents participating in the reaction taking place, as 


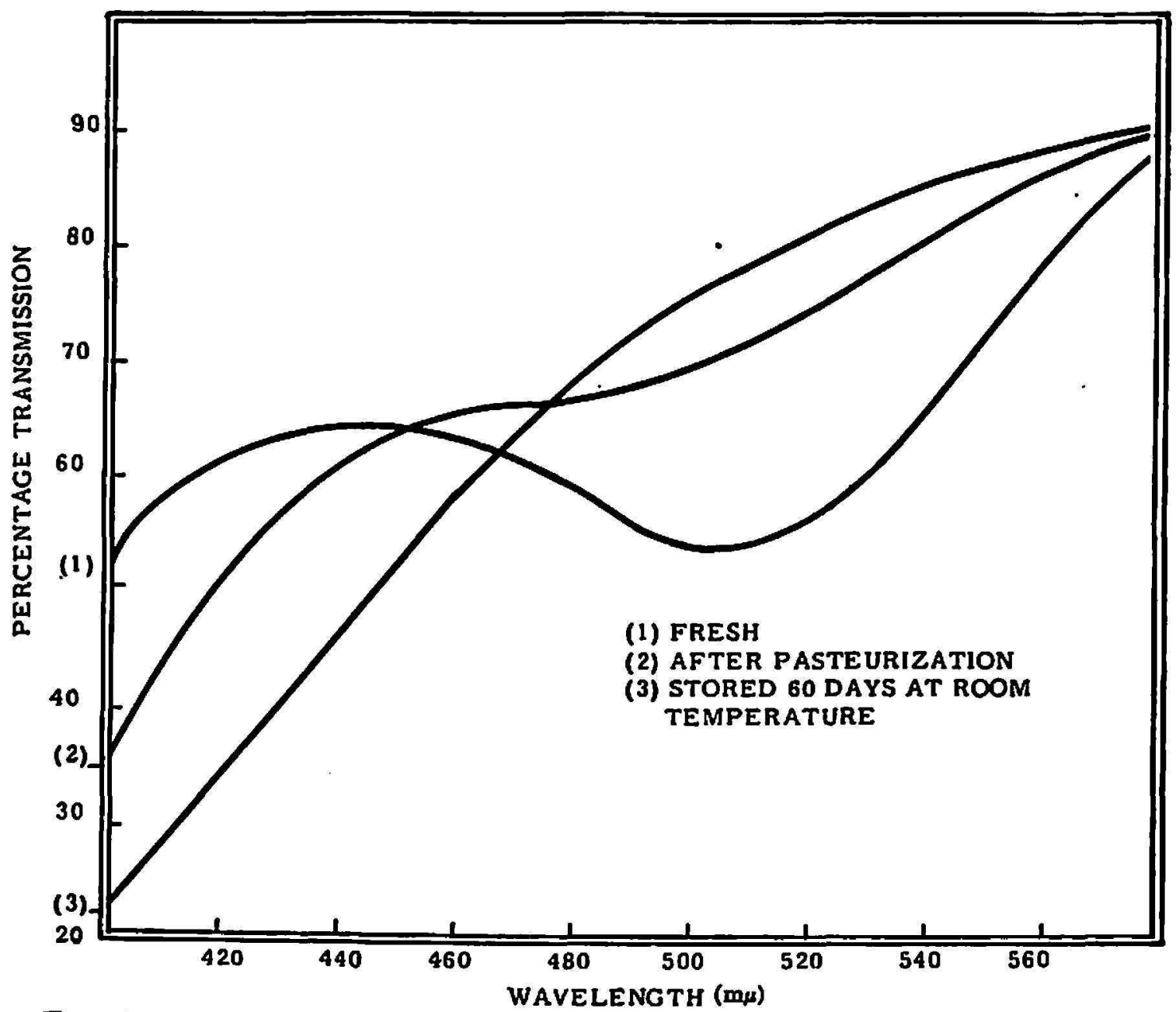

FIa. 4.-Absorption curve of a sample of acerola juice when fresh, after pasteurization, and after storage at room temperature for 60 days.

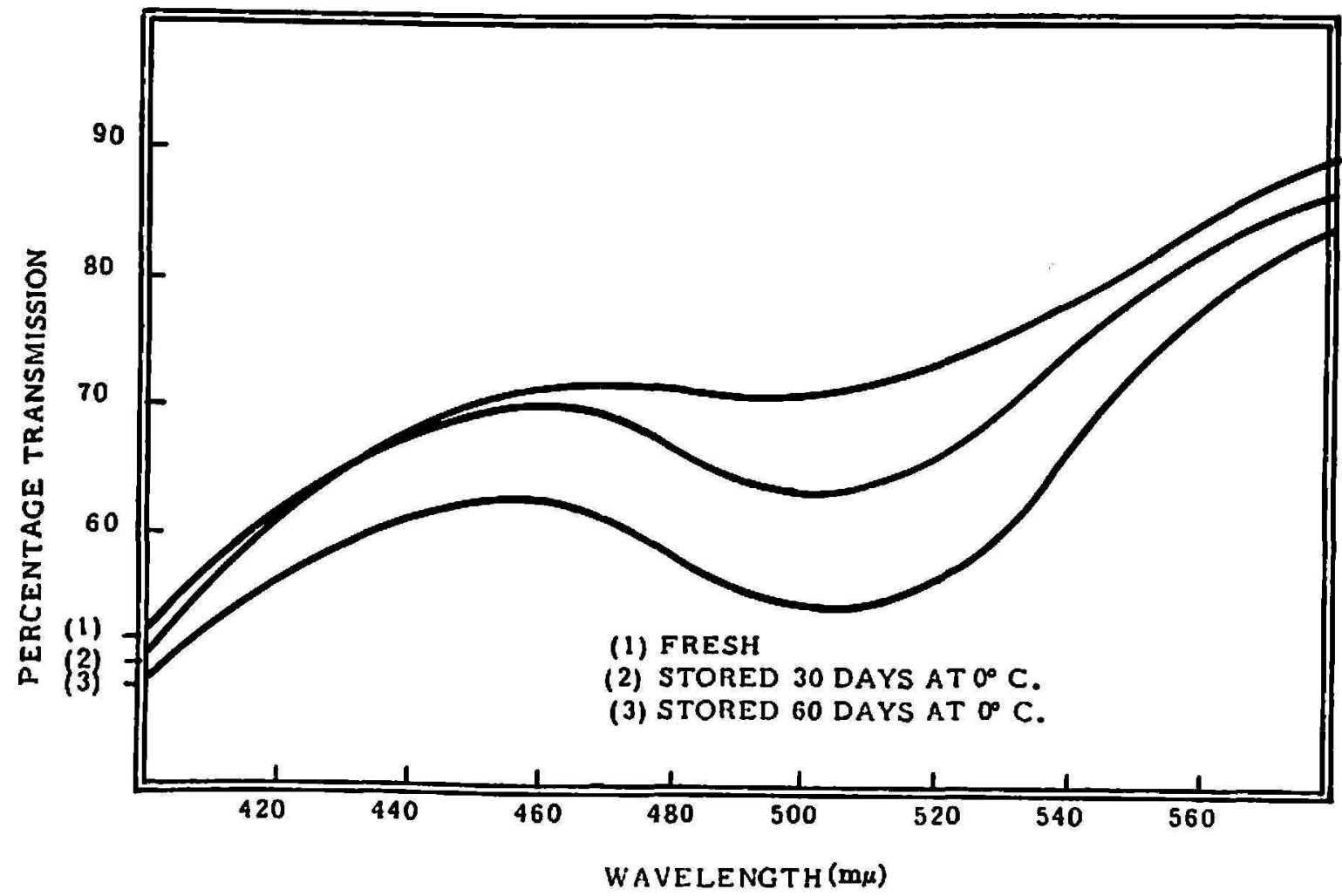

Fic. 5.-Absorption curve of a sample of acerola juice when fresh and after storage at 30 and at 60 days at $0^{\circ} \mathrm{C}$. 
has been suggested by others $(6,13$ and 14$)$ in their work with strawberry juice.

\section{. SUMMARY}

The bright red color of the expressed juice of the acerola changed to yellowish after pasteurization and, upon standing 2 months at room temperature, to brownish, and $\mathrm{CO}_{2}$ gas was produced, with subsequent swelling of the cans. Frozen juices stored for the same period remained red in color.

'A method for isolating and crystallizing the anthocyanin pigment present in the acerola juice has been described. Evidence has been presented which shows that this anthocyanin is malvin.

Data presented in this paper suggest the possibility of two nonenzymatic reactions occurring in the acerola juice and the possible participation of ascorbic acid in these reactions.

\section{RESUMEN}

El color rojo brillante del jugo de acerola cambia inmediatamente después de pasteurizar a un color rojo-amarillo. Después de almacenado por dos meses a temperaturas atmosféricas ordinarias, el color cambia a pardo y produce $\mathrm{CO}_{2}$. En jugos congelados que han estado almacenados por el mismo período, el color se ha mantenido rojo.

Se describe el método para aislar y cristalizar la antocianina presente en la acerola. Esta antocianina ha sido identificada como malvina.

Los datos experimentales obtenidos de este trabajo nos sugieren la posibilidad de dos reacciones químicas que ocurren en el jugo de acerola y la posible participación del ácido ascórbico en estas reacciones.

\section{LITERATURE CITED}

1. Asenjo, C. F., and Freire de Guzmán, A. R., Sci. 103 219, 1946.

2. Sánchez Nieva, F., J. Agr. Univ. P. R. 39 (4) 175-83, 1955.

3. Santini, Jr., R., J. Agr. Univ. P. R. 37199 (3) 1953.

4. Sondheimer E., and Kertesz, Z. I., J. Am. Chem. Soc. 70 3476, 1948.

5. - Anal. Chem. 20 (3) 245, 1948.

6. Nebesky, E. A., Esselen, W. B., Jr., McConnell, J. E. W., and Fellers, C. R., Food Res. 14 261-74 1949.

7. Gilman, Henry, Organic Chemistry, Vol. II, 1316-39, John Wiley \& Sons Inc., New York, N. Y., 1944.

8. Elderfield, E. C., Heterocyclic Compd., Vol. II, 329-39 John Wiley \& Sons, New York, N. Y., 1951.

9. Bradley, W., and Robinson, R., J. Chem. Soc. Part I, 1562, 1928.

10. Robertson, A., and Robinson, R., Biochem. J. 23 35-40, 1929.

11. Ballantine, R., Ind. Eng. Chem., Anal. Ed. 13 89, 1941.

12. Haas, V. A., Stadtman, E. R., Stadtman, F. H., and Mackinney, G., J. Am. Chem. Soc. 70 3576, 1948.

13. Beattie, H. C., Wheeler, K. A., and Pederson, C. S., Food Res. 8 395-404, 1943.

14. Pederson, C. S. Beattie, H. D., and Statz, E. H., N. Y. State Agr. Exp. Sta. Bul. 728 1-28, 1947. 